ZOOLOGIA 28 (2): 269-279, April, 2011

doi: $10.1590 /$ S1984-46702011000200018

\title{
Identification key to the Gerridae (Insecta: Heteroptera: Gerromorpha) from the Amazon River floodplain, Brazil, with new records for the Brazilian Amazon
}

\author{
Felipe F. F. Moreira' ${ }^{13}$; Viviani P. Alecrim¹; José R. I. Ribeiro² \& Jorge L. Nessimian' \\ ${ }^{1}$ Laboratório de Entomologia, Departamento de Zoologia, Instituto de Biologia, Universidade Federal do Rio de Janeiro. \\ Avenida Carlos Chagas Filho, 373, CCS, bloco A, sala 107, Cidade Universitária, Caixa Postal 68044, 21941-971 Rio de \\ Janeiro, RJ, Brazil. \\ ${ }^{2}$ Universidade Federal do Pampa, Campus São Gabriel. Avenida Antônio Trilha 1847, Centro, 97300-000 São Gabriel, RS, Brazil. \\ ${ }^{3}$ Corresponding author. E-mail: felipento@hotmail.com
}

\begin{abstract}
Eighteen species from seven genera are recorded from the Amazon River floodplain, Brazil. An identification key, diagnoses, drawings, and taxonomic and biological notes are given for these species. The main features used in the identification key and diagnoses are: body and leg segments proportions, coloration patterns, presence and distribution of setae, and modifications of the apical abdominal segments and external genitalia of the male. Based on material collected in the floodplain streams and lakes, Cylindrostethus bassleri Drake, 1952 is recorded for the first time from Brazil, and new municipality records are presented for Brachymetra lata Shaw, 1933, B. shawi Hungerford \& Matsuda, 1957, C. erythropus (Herrich-Schäffer, 1850), C. linearis (Erichson, 1848), C. Palmaris Drake \& Harris, 1934, C. regulus (White, 1879), Neogerris lotus (White, 1879), N. lubricus (White, 1879), N. visendus (Drake \& Harris, 1934), Ovatametra obese Kenaga, 1942, Rheumatobates crassifemur esakii Schroeder, 1931, R. klagei Schroeder, 1931, and Trepobates taylori (Kirkaldy, 1899). Additional new records from the Brazilian Amazon are presented for B. lata and O. obesa.
\end{abstract}

KEY WORDS. Aquatic insects; Hemiptera; Neotropics.

The Amazon River floodplain is one of the most important Amazonian ecosystems in terms of biodiversity, and the most productive Amazonian environment, occupying an area of more than $100,000 \mathrm{~km}^{2}$. It includes small tributaries, open water lakes, floating meadows and a great extension of seasonally flooded forests. Among the aquatic insect fauna in floodplains, several aquatic heteropteran species are present, but the knowledge on their distribution is scarce (Goulding et al. 2003, Nessimian et al. 2008).

Gerridae comprise a group of semi-aquatic bugs that spend almost their entire lives skating above the water surface of lentic and lotic environments, and even on open ocean, as it is the case in some genera (ANdersen 1982, Schun \& Slater 1995). Approximately 750 species are distributed among sixty genera and eight subfamilies of Gerridae, out of which only Eotrechinae Andersen, 1975 and Ptilomerinae Esaki, 1927 do not occur in South America (Andersen 1982, Polhemus \& Polhemus 2008).

Representatives of 16 species and seven genera of Gerridae have already been collected in the Amazon River floodplain, mainly in localities near major cities (DraKe \& Harris 1930, 1934, 1935, Shaw 1933, Kuitert 1942, Kenaga 1942, Hungerford 1954, Hungerford \& Matsuda 1957, Nieser 1970). In the present paper, a survey of the gerrids found in the Amazon River floodplain is presented, including an identification key, drawings, diagnoses, and new records of represented species.

\section{MATERIAL AND METHODS}

The study area included twenty-six localities in the floodplain of the Amazon River in Brazilian territory, between the municipalities of Tabatinga, state of Amazonas, and Afuá, state of Pará (Fig. 1). The examined material was collected from floating plants of the genus Eichhornia or on U.V. light traps positioned near water, and additional qualitative collections were conducted in streams (igarapés) and lakes near the sampling sites. Even with the additional collections, no Gerridae specimens have been found in some of the localities.

Specimens were deposited in the Instituto Nacional de Pesquisas da Amazônia (INPA) and Coleção Entomológica Professor José Alfredo Pinheiro Dutra, Departamento de Zoologia, Instituto de Biologia, Universidade Federal do Rio de Janeiro (DZRJ). Additional material from other regions of the Brazilian Amazon deposited in the INPA collection has been examined.

Identification of specimens was based mainly on DRAKE \& Harris (1934), KuItert (1942) and Nieser $(1970,1994)$. Illustrations were made with the help of a stereoscopic microscope 
with camera lucida. All distributional records are given from north to south. New records are followed by an exclamation mark. Abbreviations for Brazilian states are as follows: Roraima (RR), Pará (PA), Amazonas (AM), Mato Grosso (MT), Rondônia (RO), Distrito Federal (DF), Minas Gerais (MG), Espírito Santo (ES), São Paulo (SP), Rio de Janeiro (RJ).

No specimens of Limnogonus recurvus Drake \& Harris, 1930, Ovatametra fusca Kenaga, 1942 or Rheumatobates minutus flavidus Drake \& Harris, 1942 were observed by us, but they occur in the study area and have been included in the present study.

\section{TAXONOMY}

\section{Key to the adult Gerridae from the Amazon River FLOODPLAIN, BRAZIL}

1a. Eyes reniform; inner eye margin concave (Fig. 2) ........... 2

1b. Eyes not reniform; inner eye margin convex or straight (Fig. 3). 11

2a (1a). Body cylindrical and elongated, longer than four times its width; antennae short in relation to body length; antennomere IV short and curved; rostrum short, not passing posterior margin of prosternum

[Cylindrostethus] 3

2b. Body more robust, shorter than four times its width; antennae and antennomere IV longer; rostrum longer, at least passing posterior margin of prosternum ................. 7

3a (2a). Mesonotum uniformly colored, longitudinally impressed on sides; male last abdominal sternite deeply centrally notched (Fig. 4); basal portion of male genital segment II with a pair of long, anterolaterally directed projections (Figs 4 and 5)

3b. Mesonotum with a conspicuous dark stripe on each side; male last abdominal sternite concavous on posterior margin, not deeply notched (Fig. 6); basal portion of male genital segment II with a pair of short plate-like projections (Figs 6 and 7)

4a (3a). General color fuscous to black; last abdominal sternite of male with a distinct, wide spine on center of posterior margin (Fig. 4); male connexival spines long and wide, slightly curved outward (Figs 4 and 5); male genital segment II with wide basal projections (Figs 4 and 5)

Cylindrostethus erythropus

4b. General color brown; last abdominal sternite with spine, if present, smaller (Fig. 8); male connexival spines shorter and narrower (Fig. 9); male genital segment II with narrower basal projections (Figs 8 and 9)

5

$5 \mathrm{a}(4 \mathrm{~b})$. General color dark ferrugineous brown; last abdominal sternite of male without spine on posterior margin (Fig. 10) C. bassleri

5b. General color orange brown or reddish-brown; last abdominal sternite of male with a short, downward reflexed spine on center of posterior margin (Fig. 8) ...... C. linearis 6a (3b). Antennomeres I-II black; male connexival spines reaching middle of genital segment I (Fig. 7); female connexival spines long and curved, reaching apex of genital segments

C. palmaris

6b. Antennomeres I-II brown; male connexival spines not reaching middle of genital segment I (Fig. 11); female connexival spines short, not reaching apex of genital segments C. regulus

$7 \mathrm{a}(2 \mathrm{~b})$. Pronotum dark brown to black, with a pair of elongated light maculae centrally; middle tarsi with claws; connexival spines present [Limnogonus] 8

7b. Pronotum dark brown to black, with an oval central light macula; middle tarsi without claws; connexival spines absent [Neogerris] 9

8a (7a). Male genital segment I with a single spine-like projection (Fig. 24) .............. Limnogonus aduncus aduncus

8b. Male genital segment I with a rounded gibbosity in front of the posterior spine-like projection . L. recurvus

$9 \mathrm{a}(7 \mathrm{~b})$. Pronotum of apterous forms wider than long, exposing most of mesonotum (Fig. 12); male genital segment II with a tuft of setae on each side (Fig. 13) ...... Neogerris visendus

9b. Pronotum of apterous forms longer than wide, reaching at least the middle of mesonotum (Fig. 14); male genital segment II without tuft of setae.... 10

10a (9b). Eyes short and globose (Fig. 15); pronotum of apterous forms usually reaching only the middle of mesonotum (Fig. 14), rarely longer; fore femur with an ovate black spot on distal third of outer surface; posterior margin of male genital segment I with a distinct central notch N. lotus

10b. Eyes longer, not globose, pronotum of apterous forms always covering most of mesonotum, almost reaching metanotum (Fig. 16); fore femur with a brown macula occupying most of distal half; posterior margin of male genital segment I not or hardly notched .......... N. lubricus

11a (1b). Pronotum generally uniformly orange brown; tarsomere II of fore leg shorter than twice the length of tarsomere I [Brachymetra] 12

11b. Pronotum yellow to black, generally with distinct marks; tarsomere II of fore leg longer than twice the length of tarsomere I 13

12a (11a). Eyes relatively short (Fig. 3); fore femur without black pegs; male genital segment II with a distinct notch on posterior margin Brachymetra shawi

12b. Eyes long, with posterior portion well developed (Fig. 17); fore femur with numerous black pegs on venter (Fig. 18); male genital segment II without notch on posterior margin B. lata

13a (11b). Middle femur longer than middle tibia or posterior femur; antennae and hind legs bent or strongly modified in males of some species (Figs 19 and 20)

[Rheumatobates] 14 


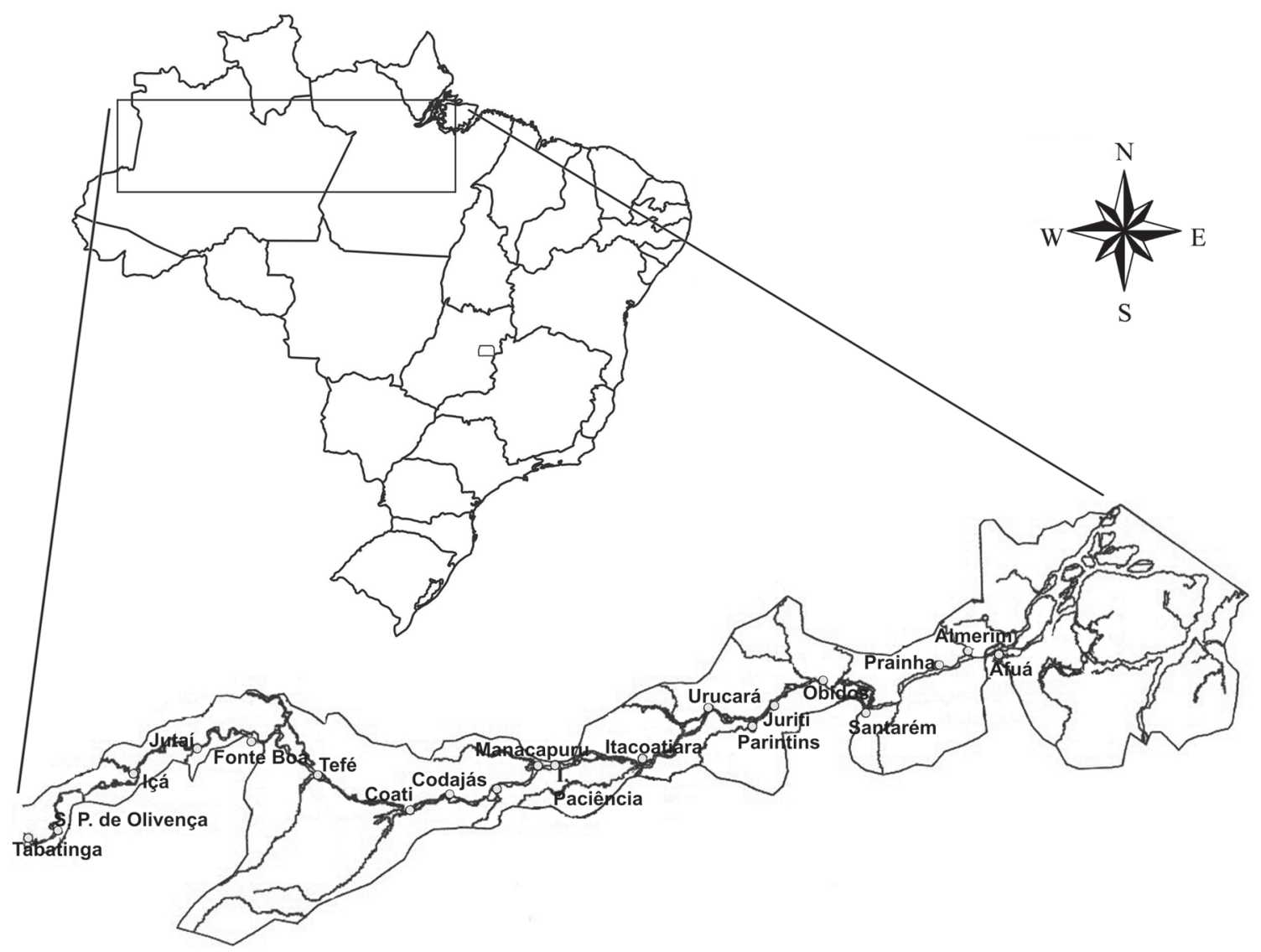

Figure 1. Map showing the location of the Amazon River floodplain and the collecting localities along the river course.

13b. Middle femur shorter than middle tibia or posterior femur; antennae and legs cylindrical, never modified ... 16

14a (13a). Thorax mostly flavous, contrasting with black body; male hind legs unmodified ... Rheumatobates minutus flavidus

14b. Thorax dark brown to black, with lighter spots near anterior margin; male hind legs strongly modified (Fig. 20)

... 15

15a (14b). Male antennomere I thickened (Fig. 19); dorsoapical surface of male antennomere IV with a tuft of long, thick black setae (Fig. 21); male hind femur without basal tuft of anteriorly directed setae, with apical fringe of long setae (Fig. 20) R. crassifemur esakii

15b. Male antennomere I long and thin (Fig. 22); dorsoapical surface of male antennomere IV without tuft of setae (Fig. 22); male hind femur with basal tuft of anteriorly directed setae, without apical fringe of long setae (Fig. 23).

R. klagei

$16 \mathrm{a}(13 \mathrm{~b})$. Middle tibia as long as or longer than body Trepobates taylori

16b. Middle tibia shorter than body [Ovatametra] 17 17a (16b). Posterior margin of abdominal tergite VII with tuft of short black setae O. obesa

17b. Posterior margin of abdominal tergite VII without tuft of black setae O. fusca

\section{SPECIES STUDIED AND THEIR DISTRIBUTION \\ Brachymetra lata Shaw, 1933}

General color of specimens is reddish-brown, with some dark-brown areas, usually more distinct in males than in females. Macropterous individuals display forewings reddishbrown to dark-brown with yellow veins. Diagnostic features include eyes with posterior part well developed (Fig. 17), and fore femur only slightly wider than middle femur, with black peg on venter (Fig. 18). It can also be distinguished from $B$. shawi Hungerford \& Matsuda, 1957 by the shorter pronotum of macropterous forms, which has a blunt apex (Fig. 17), and venter of male genital segment II without a notch on posterior margin.

Brachymetra lata is common in northern Brazil (PA, AM) and in Suriname, living preferably on streams (NIESER 1970). No specimen from the Amazon River floodplain was examined, 
but the species was recorded from the area by SHAw (1933). Several individuals from INPA were seen, most of which collected in streams and rivers. They tend to be gregarious and can be the most abundant gerrid species in lowland forest streams in Brazilian Amazon (F. F. F. Moreira personal observations), although a specimen from higher altitudes near Pico da Neblina was observed. Both apterous and macropterous forms might occur within a single population.

Examined material from the Amazon River floodplain. Brazil, Amazonas: Coari! (Urucu, igarapé, -4.86894/-65.11222), 1 apterous male, 04.II.2006, S.R.M. Couceiros leg., INPA.

Additional material. Brazil, Amazonas, São Gabriel da Cachoeira! (Pico da Neblina, $0^{\circ} 40^{\prime} \mathrm{N} / 66^{\circ} 0^{\prime} \mathrm{W}$ ), 1 apterous male, 05-12.XI.1977, R. Best leg., INPA. Presidente Figueiredo (AM240 , km 60, Sítio do Rodrigo, igarapé II, 0159’27”S/ $\left.59^{\circ} 31^{\prime} 35^{\prime \prime} \mathrm{W}\right), 3$ apterous males, 2 apterous females, 14.IX.2002, D.L.V. Pereira leg., INPA. Manaus, 1 apterous female, 07.V.1976, A.P.A. Luna Dias leg., INPA. Manaus (Cuieiras River, -2.070534/ -60.38371), 1 apterous male, 1 macropterous female, B.S. Godoy leg., INPA; (-2.458650/-60.34600), 1 macropterous male, 1 macropterous female, INPA; (-2.523500/-60.33480), 1 macropterous female, INPA; (-2.536120/-60.31720), 1 macropterous male, INPA; (-2.562880/-60.31760), 6 apterous males, 1 macropterous male, 7 macropterous females, INPA; (-2.695930/-60.29520), 15 apterous males, 16 apterous females, 1 macropterous female, INPA; (-2.707920/-60.36618), 1 apterous female, 1 macropterous female, INPA. Manaus (Urubu River, -2.115444/-59.98908), 1 apterous female, B.S. Godoy leg., INPA; (-2.161000/-60.09822), 1 apterous female, INPA; (-2.209806/-59.81064), 1 macropterous male, 1 apterous female, INPA; (-2.309111/-59.67281), 4 apterous males, 6 apterous females, INPA; (-2.445389/59.53792), 7 apterous males, 13 apterous females, INPA; (-2.517028/-59.72047), 3 apterous males, 9 apterous females, INPA; (-2.580444/-59.43950), 1 apterous male, INPA. Manaus (Tarumã River, -2.566833/-60.09831), 3 apterous males, 9 macropterous males, 4 apterous females, 11 macropterous females, B.S. Godoy leg., INPA; (-2.587222/-60.11972), 2 apterous males, 3 macropterous males, 9 apterous females, INPA; (-2.610528/59.99069), 2 apterous males, 5 macropterous males, 6 apterous females, 3 macropterous females, INPA; (-2.638028/-60.15450, 11 apterous males, 3 macropterous males, 6 apterous females, 1 macropterous female, INPA; (-2.667028/-59.89036), 4 apterous males, 8 apterous females, INPA. Manaus (Reserva Florestal Adolpho Ducke, Igarapé Tinga), 7 apterous males, 8 apterous females, B.S. Godoy leg., INPA. Manaus (Reserva Florestal Adolpho Ducke, Igarapé Acará), 22 apterous males, 25 apterous females, B.S. Godoy leg., INPA. Manaus (Reserva Florestal Adolpho Ducke, Igarapé Ipiranga), 6 apterous males, 13 apterous females, B.S. Godoy leg., INPA. Manaus (Reserva Florestal Adolpho Ducke, Igarapé Bolívia), 27 apterous males, 18 apterous females, B.S. Godoy leg., INPA. Manaus (Reserva Florestal Adolpho Ducke, Igarapé Barro Branco), 5 apterous males, 6 apterous females, 15.IX.2008, F.F.F. Moreira leg., INPA. Manaus
(Reserva Florestal Adolpho Ducke, tributary of Igarapé Acará), 1 macropterous male, 3 apterous females, F.F.F. Moreira leg., INPA. Rio Preto da Eva! (Preto da Eva River, -2.531139/59.73667), 1 apterous female, B.S. Godoy leg., INPA; (-2.637389/ -59.73667), 1 macropterous male, 2 apterous females, B.S. Godoy leg., INPA.

\section{Brachymetra shawi Hungerford \& Matsuda, 1957}

Brachymetra shawi can be distinguished from other Brachymetra by the unmarked pronotum, which reaches at least the middle of metacetabula and is narrowly rounded at apex in winged forms; forewings reddish-brown, much darker than pronotum, with yellow veins; and venter of male genital segment II with a distinct notch at middle. Eyes (Fig. 3) are not strongly produced posteriorly as in B. lata, and there are no black pegs in fore femur. Representatives of $B$. shawi are usually found in streams and rivers, but can also be collected in lentic environments, such as ponds (Nieser 1970), in Trinidad \& Tobago, the Guyanas, Brazil (PA, AM) and Bolivia. No further details on their biology are available in the literature, but they seem to be rarer than B. lata, sometimes being found in reduced numbers among larger agglomerations of individuals of the latter species (personal observations).

Examined material from the Amazon River floodplain. Brazil, Pará: Almeirim! (Nova Arumanduba, Grande Lake), 1 macropterous male, 07.X.2003, P. de Marco \& N. Ferreira-Jr. leg., DZRJ.

\section{Cylindrostethus bassleri Drake, 1952}

This species is part of the group of Neotropical Cylindrostethus in which the mesonotum displays uniform coloration and is longitudinally impressed on sides. In addition, the last abdominal sternite of male has a deep central notch (Fig. 10), the genital segment I is dorsally large, not narrowed posteriorly, and the genital segment II bears a pair of long basal projections directed anterolaterally (Fig. 10). Individuals of $C$. bassleri can be differentiated from C. erythropus (HerrichSchäffer, 1850) and C. linearis (Erichson, 1848) by the dark ferruginous brown color, and absence of a spine on posterior margin of last abdominal sternite of male (Fig. 10). Members of $C$. bassleri can also be separated from those species by their average larger size (15.8-18.8 $\mathrm{mm}$ against 12.8-17.6 in other species). The depressions of male last abdominal sternites were not described by Drake (1952). However, in specimens examined here, the abdominal sternites are depressed from the posterior margin of IV to the base of VI, and there is a distinct longitudinal median carina on the base of sternite VI. Drake (1952) also stated that female connexives and connexival spines were reflexed above abdomen, with apices touching each other. In females observed, these structures were reflexed above abdomen, but apices did not touch each other. This feature is quite variable in Neotropical species of the genus, and females of the same population of a given species can display different degrees of reflection of connexives. 

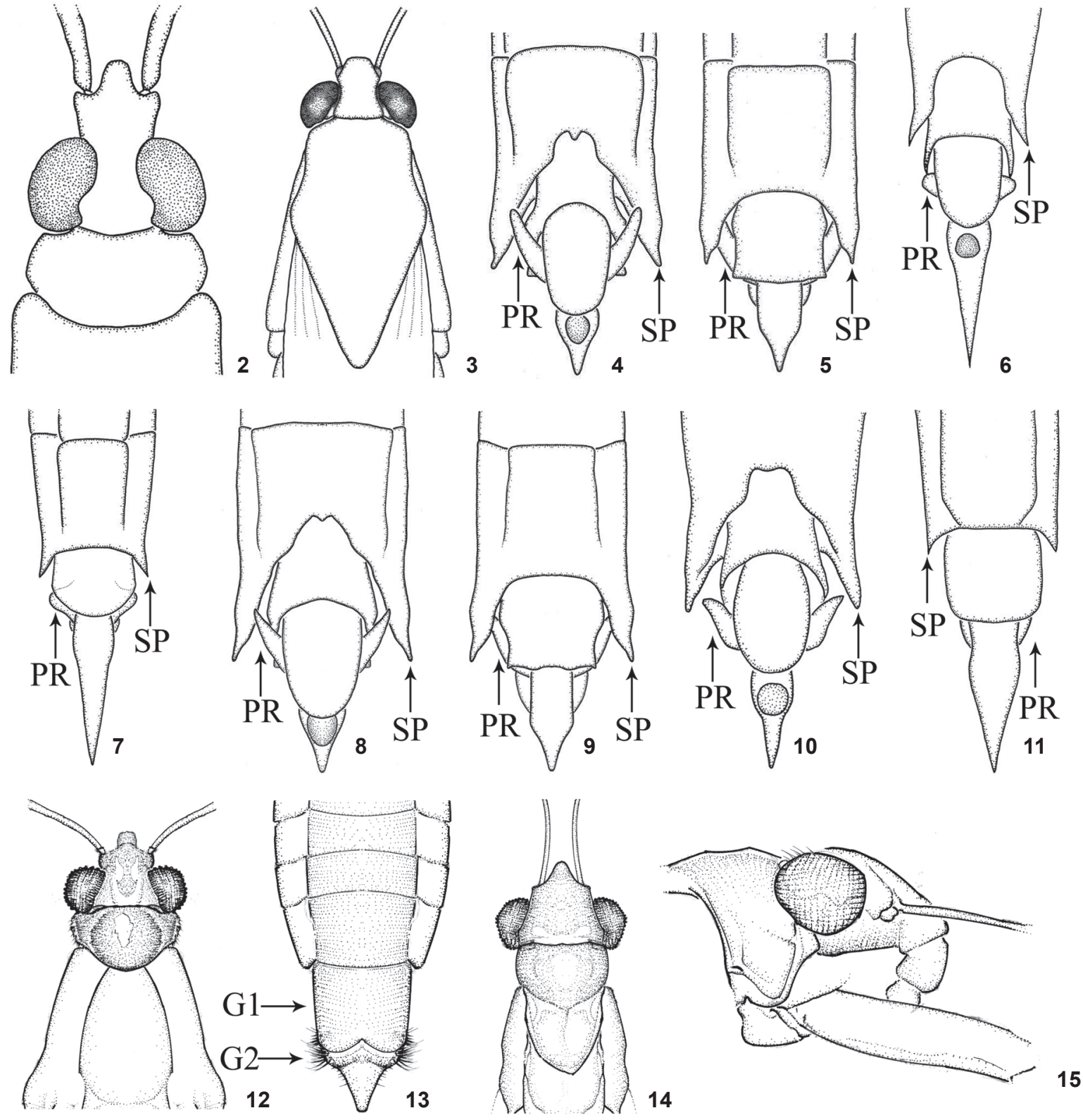

Figures 2-15. (2) Cylindrostethus bassleri, head and part of thorax, dorsal view; (3) Brachymetra shawi, head and thorax, dorsal view; (45) C. erythropus, apex of abdomen, male: (4) ventral view; (5) dorsal view; (6-7) C. palmaris, apex of abdomen, male: (6) ventral view; (7) dorsal view; (8-9) C. linearis, apex of abdomen, male: (8) ventral view; (9) dorsal view; (10) C. bassleri, apex of abdomen, male, ventral view; (11) C. regulus, apex of abdomen, male, dorsal view; (12) Neogerris visendus, head and part of thorax, dorsal view; (13) N. visendus, apex of abdomen, male, dorsal view; (14-15) N. lotus, head and part of thorax: (14) dorsal view; (15) lateral view. (G1) Genital segment I, (G2) genital segment II, (PR) projection of genital segment II, (SP) connexival spine.

This is the first record of C. bassleri from Brazil, and the first record of the species after its description from Peru. Biological information about this water strider is unavailable, except for its occurrence in lotic environments. The specimens examined were collected in a small stream, tributary of the Sapó River, in coexistence with a larger population of $C$. erythropus. The stream is shallow and narrow, probably of first order, with bottom composed of sand and litter, and slow wa- 
ter current. Primary and secondary forests are the dominant vegetation of the area, and canopy opening was only partial.

Examined material from the Amazon River floodplain. BraziL!, Amazonas: Jutaí (igarapé tributary of Sapó River, $\left.2.76119^{\circ} /-66.79997^{\circ}\right), 1$ apterous male, 3 apterous females, 06.IX.2003, N. Hamada \& J. L. Nessimian leg., INPA.

\section{Cylindrostethus erythropus (Herrich-Schäffer, 1850)}

Differences in relation to other members of the same species group (C. linearis, C. bilobatus Kuitert, 1942, and C. bassleri) include color fuscous to black, male connexival spines large and long, slightly curved outward (Figs 4 and 5), last two or three male abdominal sternites longitudinally impressed on center, and projections of male genital segment II wide (Figs 4 and 5). Females display connexival spines much shorter than in males, last abdominal sternite with a triangular projection on middle of posterior margin, and genital segment I dorsally as long as wide, narrowed posteriorly, with rounded apex.

Most of the previous records of the species were made based on material collected from large rivers (Drake \& HarRIS 1934, Kuitert 1942, Nieser 1970), at altitudes up to $350 \mathrm{~m}$ (Molano-Rendón et al. 2005) in Colombia, Brazil (PA, AM, RO), Ecuador and Peru. Molano-Rendón et al. (2008) stated that individuals prefer living on the margins of fast running, small streams in Colombia. On the water surface of the lakes and streams sampled, members of the species were found in large numbers, showing a tendency to gregarism. They also displayed the behavior of resting above the water line on tree trunks, as previously mentioned by Rоваск (1966).

Examined material from the Amazon River floodplain. BRAzIL, Amazonas: Jutaí! (São Raimundo, Bosco Lake, -2.68867\% $\left.-66.87529^{\circ}\right), 1$ apterous male, 1 apterous female, 06.IX.2003, N. Hamada \& J.L. Nessimian leg., INPA. Jutaí! (stream tributary of Sapó River, $\left.-2.76119^{\circ} /-66.79997^{\circ}\right), 15$ apterous males, 29 apterous females, 06.IX.2003, N. Hamada \& J.L. Nessimian leg., INPA. Codajás (Urucuruzinho, Urucuri Lake, -3.91960\%-62.04738 ${ }^{\circ}$ ), 1 apterous male, 15.IX.2003, N. Hamada \& J.L. Nessimian leg., INPA. Codajás (Cuxuará Lake, -3.97121\%-61.96065), 54 apterous males, 41 apterous females, N. Hamada \& J.L. Nessimian leg., DZRJ. Coari! (Monte das Oliveiras, Quintino Lake, -3.89341\%-63.35261), 1 apterous male, 12.IX.2003, N. Hamada \& J.L. Nessimian leg., INPA.

\section{Cylindrostethus linearis (Erichson, 1848)}

Members of this species share the uniformly colored mesonotum and general aspect of male external genitalia with C. erythropus, C. bilobatus and C. bassleri. Cylindrostethus linearis, and can be diagnosed by the orange-brown to reddish-brown color, relatively short and narrow male connexival spines (Figs 8 and 9), last male abdominal sternite depressed near anterior margin, with central spine on posterior margin short and reflexed downward (Fig. 8), and projections of male genital segment II curved and slender (Figs 8 and 9).

Considering the few records that provided habitat information, previous collections of $C$. linearis were made exclusively in rivers (Drake \& Harris 1934, Kuitert 1942, Nieser 1970). Speci- mens examined here were collected in only two of the lakes studied, co-existing with C. erythropus in both cases. DraKe \& HARRIS (1941) mentioned that the species occurs in the state of Rio de Janeiro, but there is no evidence that its distribution extends that far south. The current distributional range of the species extends from Guyana to Peru and Bolivia, including the Brazilian states of Pará, Amazonas and Rondônia.

Examined material from the Amazon River floodplain. Brazil, Amazonas: Codajás! (Urucuruzinho, Cuxuará Lake, $\left.3.97121^{\circ} /-61.96065^{\circ}\right), 15$ apterous males, 12 apterous females, 16.IX.2003, N. Hamada \& J.L. Nessimian leg., DZRJ. Coari! (Monte das Oliveiras, Quintino Lake, -3.89341\%-63.35261), 3 apterous males, 3 apterous females, 12.IX.2003, N. Hamada \& J.L. Nessimian leg., INPA.

\section{Cylindrostethus palmaris Drake \& Harris, 1934}

Specimens of C. palmaris display a conspicuous longitudinal dark stripe on each side of mesonotum, last male abdominal sternite concavous, without deep central notch (Fig. 6), male genital segment I dorsally narrowed posteriorly (Fig. 7), and base of male genital segment II with a pair of short plate-like projections (Figs 6 and 7). They can be separated from other Neotropical species with same features by antennomere I distinctly longer than head width across eyes, antennomeres I-II black, and male connexival spines reaching middle of genital segment I (Fig. 7). In females, connexival spines are long and genital segment I ends in an acute apex.

Representatives of $C$. palmaris are quite common and have been collected in streams, large rivers and lakes, up to $460 \mathrm{~m}$ above sea level (Kuttert 1942, Sampaio \& Py-Daniel 1993, MolanoRENDón et al. 2005). They have gregarious behavior, living preferably in non-turbulent shaded areas of streams and rivers (Hynes 1948, Nieser \& Melo 1997). In Brazil, they occur in the North, Central-West and Southeast regions (PA, AM, MT, RO, MG).

Examined material from the Amazon River floodplain. Brazil, Amazonas: Tefé! (Solimões River, Tefé Lake), 3 apterous females, 10.XII.1976, Eduardo leg., INPA.

\section{Cylindrostethus regulus (White, 1879)}

This species shares the mesonotum with lateral stripes and the structure of male genitalia with C. palmaris, $C$. hungerfordi and C. podargus Drake, 1958. Males of C. regulus can be separated from them by the antennomere I longer than width of head through eyes, antennomeres I-II brown, male connexival spines not reaching middle of genital segment I (Fig. 11), female connexival spines relatively short, and female genital segment I rounded on posterior margin. In the studied specimens, mesonotal stripes are brownish-black, lighter than those of C. palmaris, and slightly fainted before posterior third of segment. Stripes are wide and continue over metanotum, differently from $C$. hungerfordi, which possesses narrow stripes and only elongate spots on metanotum. Specimens of $C$. regulus have been collected only from rivers in the state of Amazonas (Drake \& Harris 1930, Kuitert 1942), and only one male was collected in the lakes studied. 

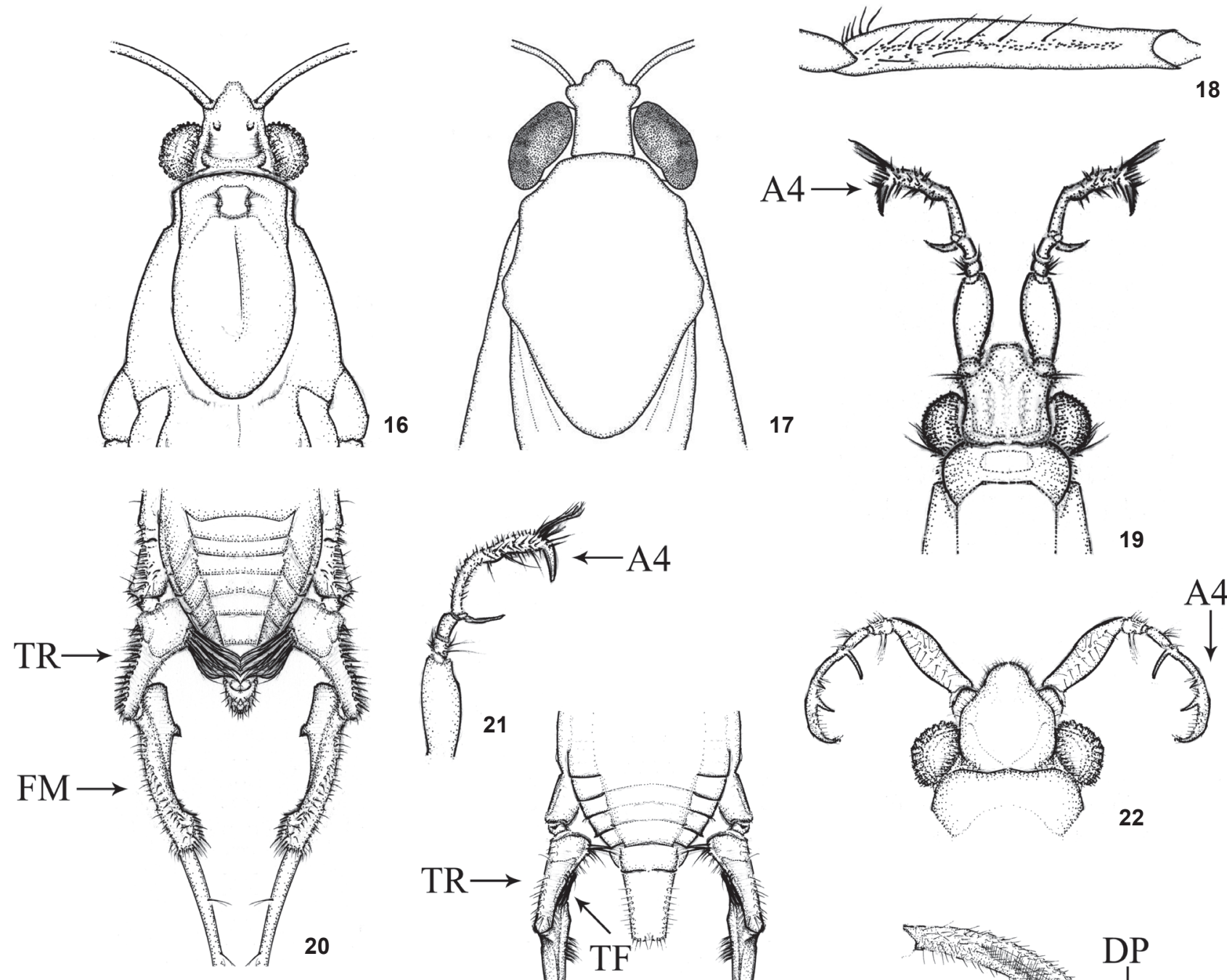

17
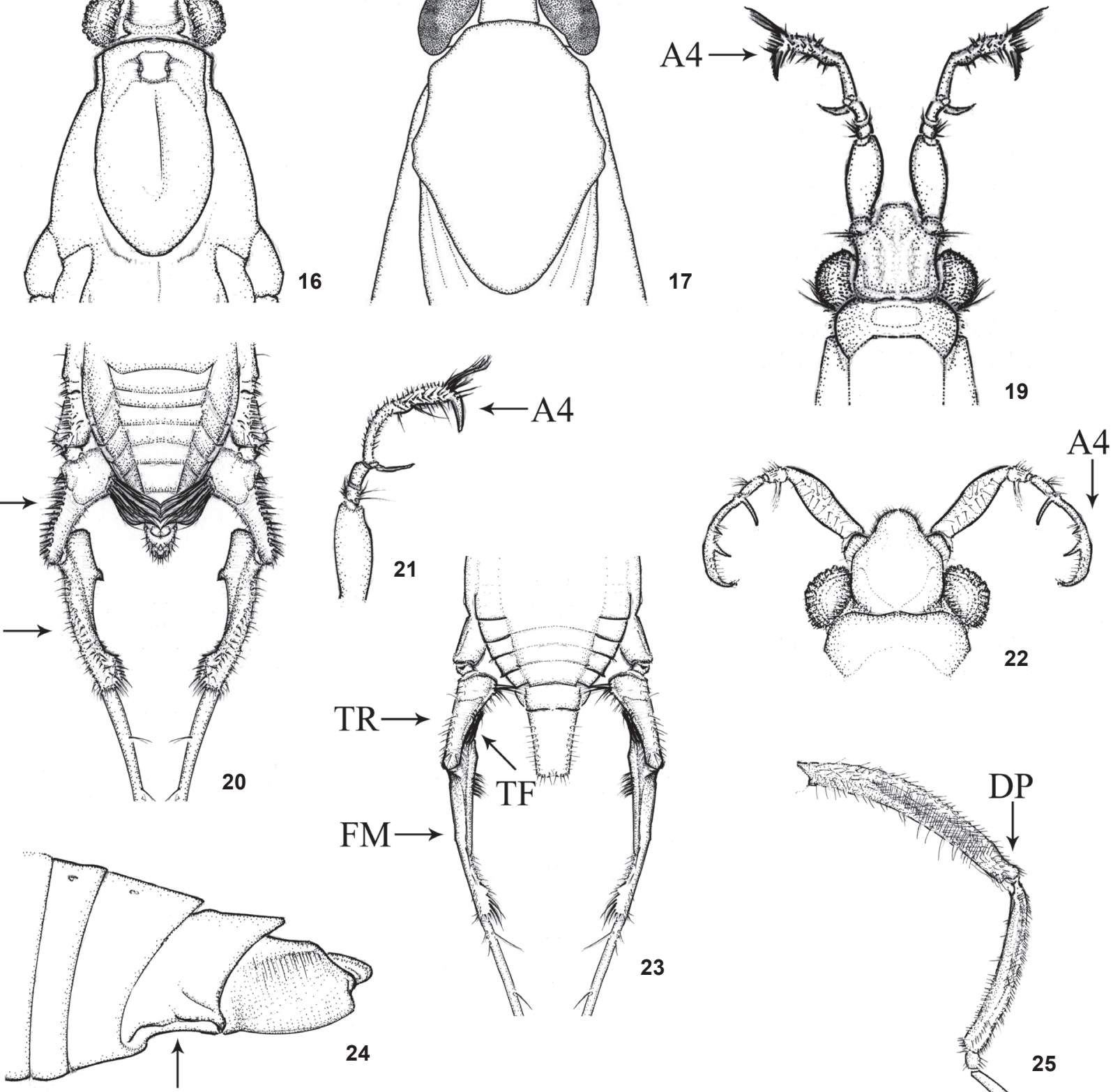

G1

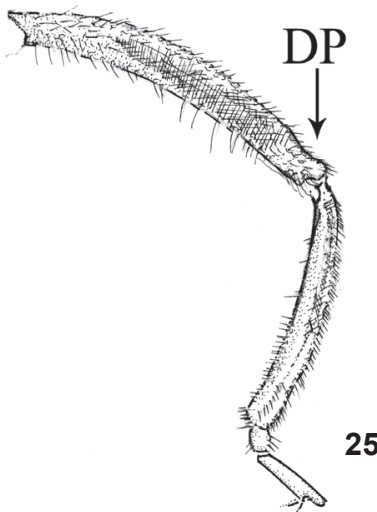

Figures 16-25. (16) Neogerris lubricus, head and part of thorax, dorsal view; (17) Brachymetra lata, head and part of thorax, dorsal view; (18) B. lata, fore femur, ventral view; (19) Rheumatobates crassifemur esakii, head and part of thorax, male, dorsal view; (20) R. c. esakii, abdomen and part of hind legs, male, dorsal view; (21) R. c. esakii, antenna, male; (22) R. klagei, head and part of thorax, dorsal view; (23) R. klagei, abdomen and part of hind legs, male, dorsal view; (24) Limnogonus aduncus aduncus, apex of abdomen, male, ventrolateral view; (25) Trepobates taylori, fore leg, male. (A4) Antennomere IV, (DP) femur depression, (FM) femur, (G1) genital segment I, (TF) anteriorly directed tuft of setae, (TR) trochanter. 
Examined material from the Amazon River floodplain. BRAZIL, Amazonas: Tefé! (São Francisco da Boca do Capivara, Botão Lake,-3.26539/-64.62745), 1 apterous male, 09.IX.2003, N. Hamada \& J.L. Nessimian leg., INPA.

Limnogonus aduncus aduncus Drake \& Harris, 1933

Males of this species can be identified by the mesosternum with a shallow wide depression, and by the venter of genital segment I without keels or gibbosities, with a small curved spine on apex (Fig. 24). Females display connexival spines moderately long and last abdominal sternite sharply produced at middle behind. In both sexes antennomere I is longer than width of head through eyes and dorsalmost part of the mesopleura is dark-brown to black with a lighter central stripe of variable size.

Representatives of the species are common throughout South America, being found in streams and rivers, stagnant water bodies with emergent vegetation, and pools of various sizes (Roback 1966, Nieser 1970, Nieser \& Melo 1997, Melo \& Nieser 2004). In Argentina they generally inhabit the margins of small streams in forested mountain areas, but can also be found in dryer areas dominated by savannas on the Chaco Plain. In the last case, the species is uncommon and probably not gregarious, with few individuals obtained in each collection (Mazzucconi \& Bachmann 1995). Even though we have found no specimens in the lakes sampled, L. aduncus had been previously recorded from the area by DRAKE \& HARRIs (1935). In Brazil, the species is distributed through the North, Central-West and Southeast regions (PA, AM, MT, MG, ES, SP, RJ).

The first author of the present work recently went to INPA and had the opportunity to examine its dried Gerridae collection. He noticed that a long series collected by Dr. B.M. Mascarenhas at INPA, Manaus, and identified by him as $L$. recurvus Drake \& Harris, 1930, like specimens cited in Mascarenhas (1979), were in fact representatives of L. a. aduncus. Some specimens had been identified and labeled as L. aduncus by Dr. J. T. Polhemus. Therefore, the records of $L$. recurvus in Mascarenhas (1979) should be instead referred to L. a. aduncus.

Additional material. Brazil, Amazonas: Manaus (INPA), 50 apterous males, 1 macropterous male, 32 apterous females, 4 macropterous females, 20-30.II.1978, B. Mascarenhas leg., INPA.

\section{Limnogonus recurvus Drake \& Harris, 1930}

Limnogonus recurvus differs from $L$. aduncus aduncus by the presence of a rounded gibbosity on male genital segment I, besides the posterior spine-like curved projection. The two species can also be separated based on the color of the mesopleura, which is brown with a light transversal stripe in L. recurvus, and usually black with a transversal light stripe in L. aduncus aduncus.

No representatives of $L$. recurvus were examined in the present study, but the species had been recorded from the Amazon River floodplain by KuITERT (1942), specifically from Lago Grande [do Curuai], Santarém, Pará. Limnogonus recurvus is also known from Bolivia and the Brazilian states of Mato Grosso, Rondônia, Goiás and Minas Gerais. Another representative of the genus, L. hyalinus (Fabricius, 1803), had been recorded from Manaus by Whiтe (1879), but no records of the species specifically from the Amazon River have been found. For this reason, we have not included L. hyalinus in this study.

\section{Neogerris lotus (White, 1879)}

This species can be distinguished from other Neotropical Neogerris by the pronotum of apterous forms relatively short, usually reaching slightly beyond half length of mesonotum (Fig. 14), and the pronotum of alate forms constricted between anterior and posterior lobes. Other features that might allow its identification are the globose eyes (Fig. 15) and the fore femur displaying an ovate spot on its outer surface, just before the apical third. In some apterous specimens, the pronotum can be longer, leaving only a small strip of the mesonotum exposed or completely covering it, as was noticed by NIESER (1994) for specimens from Mato Grosso and Trinidad and Tobago.

Members of N. lotus are distributed in a wide area, occurring in lowlands (up to $200 \mathrm{~m}$ above sea level) from the Guyanas to North and Central-West Brazil (PA, AM, MT, DF) (NIESER 1970, Molano-Rendón et al. 2005). Its representatives have been recorded from pools, ponds, and low current streams and rivers (Nieser 1994), and not much is known about their biology. Only one specimen was collected in the lakes of the Amazon River we studied. Members of this species either have a preference for habitats different from those sampled, or are associated with other hydrophyte species.

Examined material from the Amazon River floodplain. BraziL, Amazonas: Fonte Boa! (Fonte Boa, Ressaca Grande Lake, -2.47399/-66.15474), 1 apterous male, 08.IX.2003, N. Hamada \& J.L. Nessimian leg., INPA.

\section{Neogerris lubricus (White, 1879)}

The pronotum of apterous specimens of $N$. lubricus is always long, almost reaching the metanotum (Fig. 16), and that of alate forms does not show central constriction. Eyes are long, not globose; and the male abdominal tergite I is narrow, tapering to the apex, with posterior margin with very faint central notch or without notch.

Members of $N$. lubricus show the widest geographic distribution among Neotropical representatives of this genus, occurring in streams, rivers, permanent or semi-permanent pools and ponds, up to $400 \mathrm{~m}$ above sea level (NIESER 1970, Mazzucconi \& Bachmann 1995, Nieser \& Melo 1997, MolanoReNDón et al. 2005). In Brazil, the species occurs in the North, Central-West and Southeast regions (PA, AM, MT, RO, MG).

Macropterous and apterous individuals are equally common, and gregarism is not evident in the populations studied in Argentina (Mazzucconi \& Bachmann 1995). According to Nieser (1994), representatives of the species occur in the same habitats as $N$. lotus, and both are more abundant in sites rich in emergent vegetation (Nieser 1970, Mazzucconi \& Bachmann 
1995). As cited above for $N$. lotus, only one specimen of $N$. lubricus has been collected in the lakes studied, confirming their presence in the Amazon River floodplain, but probably indicating preference for mesohabitats or hydrophytes different from those sampled. Based on literature data, N. lubricus is associated with hydrophyte species of Salvinia, Azolla, and Equisetum, among other genera (Melo \& Nieser 2004), but not Eichhornia.

Examined material from the Amazon River floodplain. BraziL, Amazonas: Itacoatiara! (Trindade Island, lake on Trindade Island), 1 apterous male, 22.IX.2003, P. de Marco \& N. FerreiraJr. leg., INPA.

\section{Neogerris visendus (Drake \& Harris, 1934)}

Males of this species can be readily identified by the genital segment II bearing a distinct pair of tufts of setae (Fig. 13) on each side. In addition, antennomere I is slightly longer than head width plus an eye, the pronotum of apterous forms has no posterior lobe, being larger than longer (Fig. 12), and the pronotum of alates has no central constriction.

This species ranges from Colombia to Peru, including the North Region of Brazil (RR, PA, AM). Its representatives are commonly recorded from streams and lakes. Previous records include localities shared with $N$. lotus, but they most likely inhabit distinct microhabitats (Nieser 1970, Molano-Rendón et al. 2005). Several specimens of $N$. visendus were collected in association with Eichhornia sp. in the lakes and nearby streams sampled, but only one exemplar of $N$. lotus. Our findings corroborate the hypothesis that the two species have different habitat preference. Another representative of the genus, $N$. genticus (Drake \& Harris, 1934), was described from Santarém, but not specifically from the Amazon River floodplain. Since there have been no further records of $N$. genticus since its description, the species has not been included in the present study.

Examined material from the Amazon River floodplain. BraziL, Amazonas: Fonte Boa! (Fonte Boa, Solimões River, Ressaca Grande Lake), 23 apterous males, 1 macropterous male, 31 apterous females, 08.IX.2003, N. Hamada \& J.L. Nessimian leg., DZRJ. Jutaí! (São Raimundo, Solimões River, Bosco Lake, UV light trap), 1 macropterous male, 06.IX.2003, N. Hamada \& J.L. Nessimian leg., INPA. Jutaí! (igarapé tributary of Sapó River), 2 apterous males, 2 apterous females, 06.IX.2003, N. Hamada \& J.L. Nessimian leg., INPA. Tefé! (São Francisco da Boca do Capivara, Solimões River, igarapé), 3 apterous males, 14 macropterous males, 2 apterous females, 20 apterous females, 09.IX.2003, N. Hamada \& J.L. Nessimian leg., DZRJ. Tefé! (São João do Catuaí, Arraia Lake), 2 apterous females, 11.IX.2003, N. Hamada \& J.L. Nessimian leg., INPA.

\section{Ovatametra fusca Kenaga, 1942}

Ovatametra fusca differs from O. minima Kenaga, 1942 and O. parvula (Drake \& Harris, 1935) by its length greater than $2.50 \mathrm{~mm}$ and by the color pattern of mesonotum. Specimens of $O$. fusca do not possess a tuft of black setae on the posterior margin of abdominal tergite VII, which is present in O. obesa Kenaga, 1942. The only information available on the biology of $O$. fusca is the occurrence in rivers. Just its type-series, from Solimões River (Manacapuru, Brazil) and Supuruni Creek (British Guiana) has been collected so far.

\section{Ovatametra obesa Kenaga, 1942}

Representatives of $O$. obesa are known from the states of Pará and Amazonas. Individuals from different populations vary in coloration, but specimens from the same population are relatively uniform. Specimens examined from the Anavilhanas Archipelago have mesonotal markings similar to those of $O$. parvula and, according to Nieser (1970), the color pattern of some individuals is very similar to that of $O$. fusca. Ovatametra obesa can be separated from $O$. fusca by a tuft of black setae present on the posterior margin of abdominal tergite VII. Despite being cited only for females by Nieser (1970), this feature has also been observed in males.

Nieser (1970) examined specimens collected both in lentic and lotic environments, but material studied here was collected exclusively from lakes. The alate form of O. obesa has not yet been recorded in the literature, and in the only macropterous specimen examined the wings were broken off along a suture line near base, a feature that was observed by TorreBuENo (1908) in other Halobatinae. A third representative of the genus, O. parvula (Drake \& Harris, 1935), was described from "Amazon, Manaos", without further details. As only the type-series of the species is known, and there is no evidence of its occurrence in the Amazon River floodplain, O. parvula was not included in the present study.

Examined material from the Amazon River floodplain. Brazil, Amazonas: Parintins! (Menino Deus, Comprido Lake, 2.49865 S/-56.4908), 1 macropterous female, 25.IX.2003, P. de Marco \& N. Ferreira-Jr. leg., INPA. Tefé! (São João do Catuaí, Arraia Lake), 1 apterous male, 5 apterous females, 11.IX.2003, N. Hamada \& J.L. Nessimian leg., DZRJ.

Additional material. BraziL, Amazonas: Manaus! (Negro River, Anavilhanas Archipelago, Prato Lake), 1 apterous female, 12.VIII.1981, J.L. Nessimian leg., DZRJ; (Siriri Lake), 1 apterous female, 10.VII.1981, J.L. Nessimian leg., DZRJ; (Xidaua Lake), 1 apterous female, 23.V.1981, J.L. Nessimian leg., DZRJ; 1 apterous female, 18.IX.1981, J.L. Nessimian leg., DZRJ.

\section{Rheumatobates crassifemur esakii Schroeder, 1931}

Males of the three subspecies of Rheumatobates crassifemur Esaki, 1926 have strongly modified antennae and legs, and the hind femur is connected subbasally to the trochanter, without basal anteriorly directed tuft of setae (Fig. 20). Rheumatobates c. esakii can be distinguished from R. c. crassifemur Esaki, 1926 and R. c. schroederi Hungerford, 1954 by the male antennomere IV with a tuft of about five long erect black setae (Fig. 21).

Both adults and nymphs of $R$. c. esakii are found in lentic environments in Northern South America, including the Brazilian states of Pará and Amazonas (Nieser 1970), and occasionally occur in sympatry with $R$. klagei Schroeder, 1931. In the present study, males and females were collected associated with Eichhornia sp. and by use of U.V. light traps, which 
corresponds to the first record of capture of the species by this means. Specimens identified as $R$. bonariensis by Nessimian et al. (2008) are in fact females of $R$. c. esakii.

Examined material from the Amazon River floodplain. BRAzIL, Amazonas: Urucará! (Lírio do Vale, Albano Lake, -2.41418 S/-57.49993, U.V. light trap), 24.IX.2003, 4 macropterous males, 4 macropterous females, P. de Marco \& Nelson Ferreira-Jr. leg., DZRJ. Parintins! (Menino Deus, Comprido Lake, -2.49865/56.4908), 25.IX.2003, 4 apterous males, 1 macropterous male, 4 apterous females, 7 macropterous females, P. de Marco \& N. Ferreira-Jr. leg., DZRJ.

\section{Rheumatobates klagei Schroeder, 1931}

This species can be diagnosed based on the following male features: shape of antenna (Fig. 22) and presence of anteriorly directed tuft of setae on basal portion of hind femur, which is connected sub-basally to hind trochanter (Fig. 23). Males are similar to those $R$. c. esakii, but the latter do not possess the basal anteriorly directed tuft of setae on hind femur. As $R$. c. esakii, R. klagei was recorded from lakes of northern South America, including Pará and Amazonas states. A few individuals from Lago Janauacá, a lake rich in hydrophytes, including Eichhornia, have been observed. However, the association of $R$. klagei with this plant is not certain.

Examined material from the Amazon River floodplain. BRAZIL, Amazonas: Manaquiri! (Janauacá Lake), 1 apterous male, 9 apterous females, 01.IV.1994, T.R. Gasnier leg., INPA.

Rheumatobates minutus flavidus Drake \& Harris, 1942

Representatives of $R$. $m$. flavidus possess the most striking color pattern as compared to other species of the genus, with most of the thorax dorsally flavous, in contrast with the black body. Differently from R. c. esakii and R. klagei, male antennae and hind legs are unmodified. Besides the coloration, other diagnostic characters are antennomere III longer than others, fore femur just a little thicker than the middle one, and genital segments not distinctly hairy. Rheumatobates $m$. flavidus can be found in lentic environments, streams and rivers, sometimes on fast running areas (MAzzUCCONI 1999), and was recorded from the Amazon River (Itacoatiara) by Hungerford (1954). In Brazil, it can also be found in the states of Rondônia and Minas Gerais.

\section{Trepobates taylori (Kirkaldy, 1899)}

Males of T. taylori are distinguished from other species of the genus by the fore femur with a distinct constriction near apex (Fig. 25), middle femur and base of middle tibia with fringes of setae almost as long as the article width, and genital segments without dense pilosity. Females can be identified by the antennomere II distinctly shorter than the III, apex of connexives not strongly projected posteriorly, and last abdominal sternite without distinct pilosity on apex. Apterous forms of both males and females are similar to macropterous ones, but somewhat smaller and with reduced pronotum.

In Argentina, members of T. taylori are found only in small mountainous rivers, being common and apparently not gre- garious (MAZZuCCONI \& BACHMANN 1995). In other areas, by contrast, the species is as abundant in costal brackish lagoons and ponds as in freshwater bodies (Drake \& HotTes 1952). These data suggest that $T$. taylori has the ability to colonize very different habitats, which might contribute to its wide geographical range. Both apterous and macropterous specimens are found in the same population, and the alate ones usually bear broken wings.

In Brazil, specimens have been recorded from the states of Pará and Amazonas. Only two specimens were collected in the lakes studied by us, one being fully-winged, with a fracture line on the posterior part of the corium, which is probably used by the animal when breaking off the wings.

Examined material from the Amazon River floodplain. BraziL, Amazonas: Parintins! (Menino Deus, Comprido Lake, 2.49865 S/-56.4908), 1 apterous male, 25.IX.2003, P. de Marco $\&$ N. Ferreira-Jr. leg., INPA. Itacoatiara! (Trindade Island, lake in Trindade Island), 1 macropterous male, 22.IX.2003, P. de Marco \& N. Ferreira-Jr. leg., DZRJ.

\section{ACKNOWLEDGEMENTS}

This paper was elaborated with financial support from Conselho Nacional de Desenvolvimento Científico e Tecnológico (CNPq), Projeto Pro-Várzea/IBAMA, and Fundação de Amparo ao Desenvolvimento da Pesquisa (FADESP). We thank Bruno Spacek Godoy (UFG) and Domingos L.V. Pereira (INPA) for lending their specimens for study; and Professors Raquel Telles de Moreira Sampaio (INPA) and Augusto Loureiro Henriques (INPA) for providing access to their institutions' collections.

\section{LITERATURE CITED}

Andersen, N.M. 1982. The semiaquatic bugs (Hemiptera, Gerromorpha) phylogeny, adaptations, biogeography and classification. Entomograph 3: 1-455.

Drake, C.J. 1952. The American species of Cylindrostethus Mayr (Hemiptera, Gerridae). American Museum Novitates 1579: 1-3.

Drake, C.J. \& H.M. Harris. 1930. Notes on some South American Gerridae (Hemiptera). Annals of the Carnegie Museum 19: 235-239.

Drake, C.J. \& H.M. Harris. 1934. The Gerrinae of the Western Hemisphere (Hemiptera). Annals of the Carnegie Museum 23: 179-241.

Drake, C.J. \& H.M. HaRris. 1935. Notes on some American gerrids (Hemiptera). Arkiv för Zoologi 28B: 1-4.

Drake, C.J. \& H.M. Harris. 1941. Concerning some halobatinids from the Western Hemisphere (Hemip. Gerridae). Iowa State College Journal of Science 15: 237-240.

Drake, C.J. \& F.C. Hottes. 1952. Genus Trepobates HerrichSchaeffer (Hemiptera: Gerridae). Great Basin Naturalist 12: 35-38. 
Goulding, M.; R.B. Barthem \& E.J.G. Ferreira. 2003. The Smithsonian Atlas of the Amazon. Washington, D.C., Smithsonian Institution, 253p.

Hungerford, H.B. 1954. The genus Rheumatobates Bergroth (Hemiptera-Gerridae). University of Kansas Science Bulletin 36: 529-588.

Hungerford, H.B. \& R. Matsuda. 1957. Description of two new species of the genus Brachymetra (Gerridae, Hemiptera). Journal of the Kansas Entomological Society 30: 19-25.

Hynes, H.B.N. 1948. Notes on the aquatic HemipteraHeteroptera of Trinidad and Tobago, B.W.I., with a description of a new species of Martarega B. White (Notonectidae). Transactions of the Royal Entomological Society of London 99: 341-359.

KenagA, E.E. 1942. A new genus in the Halobatinae (Gerridae Hemiptera). Journal of the Kansas Entomological Society 15: 136-141.

KuITERT, L.C. 1942. Gerrinae in the University of Kansas collections. University of Kansas Science Bulletin 28: 113-143.

Mascarenhas, B.M. 1979. Alguns aspectos sobre morfologia e ciclo de vida de Limnogonus recurvus (Hemiptera: Gerridae). Acta Amazonica 9: 763-772.

MazzUCConi, S.A. 1999. Rheumatobates (Rheumatobates) minutus flavidus Drake y Harris en la Argentina (Insecta: Heteroptera: Gerridae). Neotrópica 45: 108.

Mazzucconi, S.A. \& A.O. Bachmann. 1995. Geographic distribution of the Gerridae in Argentina (Insecta, Heteroptera). Insecta Mundi 9: 363-370.

Melo, A.L. \& N. Nieser. 2004. Faunistical notes on aquatic Heteroptera of Minas Gerais (Brazil): an annotated list of Gerromorpha and Nepomorpha collected near Januária, MG. Lundiana 5: 43-49.

Molano-Rendón, F.; D.L. Camacho-Pinzón \& C. Serrato-Hurtado. 2005. Gerridae (Heteroptera: Gerromorpha) de Colombia. Biota Colombiana 6: 163-172.

Molano-Rendón, F.; I.T. Morales-Castaño \& C. Serrato-Hurtado. 2008. Classificación y habitats de Gerridae (Heteroptera -
Gerromorpha) en Colombia. Acta Biológica Colombiana 13: $41-60$.

Nessimian, J.L.; N. Hamada; N. Ferreira-Jr. \& P. de Marco-Jr. 2008. Entomofauna Aquática, p. 93-131. In: A.L.K.M. Albernaz (Ed.). Conservação da Várzea: Identificação e Caracterização de Regiões Biogeográficas. Manaus, Ibama/Pro-Várzea, 354p.

Nieser, N. 1970. Gerridae of the Suriname and the Amazon with additional records of other Neotropical species. Studies on the Fauna of Suriname and other Guyanas 12: 94-138.

Nieser, N. 1994. A new species and a new status in Neogerris Matsumura (Heteroptera: Gerridae) with a key to American species. Storkia 3: 27-37.

Nieser, N. \& A.L. Melo. 1997. Os heterópteros aquáticos de Minas Gerais. Guia introdutório com chave de identificação para as espécies de Nepomorpha e Gerromorpha. Belo Horizonte, Editora UFMG, 180p.

Polmemus, J.T. \& D.A. Polnemus. 2008. Global diversity of true bugs (Heteroptera; Insecta) in freshwater. Hydrobiologia 595: 379-391.

Rоваск, S.S. 1966. The Catherwood Foundation PeruvianAmazon Expedition. VIII - aquatic Hemiptera-Heteroptera. Monographs of the Academy of Natural Sciences of Philadelphia 14: 211-215.

Schun, R.T. \& J.A. Slater. 1995. True Bugs of the World (Hemiptera: Heteroptera). Classification and Natural History. New York, Cornell University Press, 336p.

Sampaio, R.T.M. \& V. Py-Daniel. 1993. A subfamília Gerrinae (Hemiptera: Heteroptera: Gerridae) na Bacia Hidrográfica do Rio Trombetas, Pará, Brasil. Acta Amazonica 23: 83-94.

SHAw, J.G. 1933. A study of the genus Brachymetra (HemipteraGerridae). University of Kansas Science Bulletin 21: 221233.

TORRE-Bueno, J.R. DE LA. 1908. The broken hemelytra in certain Halobatinae. Ohio Naturalist 9: 389-392.

Whiтe, F.B. 1879. Descriptions of new Hemiptera. (I.). Journal of the Linnean Society (Zoology) 14: 482-489.

Submitted: 06.XII.2010; Accepted: 20.III.2011.

Editorial responsibility: Gabriel L.F. Mejdalani 